\title{
FELFEDEZTETÉSES TANULÁST SEGÍTŐ GYAKORLATOK AZ OxIPO-MODELL ALAPJÁN
}

Szerzők:

Mező Ferenc (PhD)

Eszterházy Károly Katolikus Egyetem
Pinczésné Palásthy Ildikó (PhD)

Szerző e-mail címe:

ferenc.mezo1@gmail.com
Debreceni Református

Hittudományi Egyetem

Szabóné Balogh Ágota (Ph.D.)

Gál Ferenc Egyetem

\section{Lektorok:}

és további két anonim lektor...

\section{Absztrakt}

E tanulmány a „Tudomány újratöltve” projekt módszertani vonatkozásait mutatja be. A projektnek két elméleti gyökere van: Joseph Schwab elmélete a felfedeztetéses tanulásról és Mező Ferenc OxIPO tanulási modellje. Az elméleti háttér rövid összefoglalása után a módszertani megoldásokat és problémákat mutatjuk be.

Kulcsszavak: felfedeztetéses tanulás, OxIPO, tanulás

Diszciplína: pszichológia, pedagógia

\section{Abstract}

PRACTICES ON THE BASE OF OXIPO-MODEL

FOR INQUIRY-BASED LEARNING

This article shows the methodological aspects of the project 'Science: reloaded'. This project has two theoretical roots: Joseph Schwab's theory about Inquiry-Based Learning and Ferenc Mezó's OxIPO-model of learning. After a brief summary of the theoretical background, the methodology solutions and problems are presented.

Keywords: Inquiry-Based Learning, OxIPO, learning

Discipline: psychology, pedagogy

Mező Ferenc (2021): Felfedeztetéses tanulást segítő gyakorlatok az OxIPO-modell alapján. OxIPO - interdiszciplináris tudományos folyóirat, 2021/3, 83-97.

doi: 10.35405/OXIPO.2021.3.83 
Az alábbiakban az OxIPO-modell aspektusából tárgyaljuk a felfedeztető tanulás módszertani lehetőségeit. Először röviden vázoljuk az OxIPO-modell, illetve a felfedeztetéses tanulás lényegét, majd rámutatunk e két témakör kapcsolatára, végül pedig módszertani ajánlást teszünk egy akár tantermi környezetben is megvalósítható, minimális eszköz-, költség- és időigényű, és a felfedeztetéses tanulást az OxIPO-modell keretrendszerében megvalósító tanulásszervezési lehetőségre. Ennek ismertetése során a felfedeztetéses tanulással járó általános módszertani nehézségekre is kitérünk.

\section{Elméleti háttér}

Az OxIPO-projekt célja a humán információfeldolgozási kapacitás növelési lehetőségeinek kutatása, diagnosztikai eszközök, fejlesztési módszertanok kidolgozása - neurobiológiai, képességfejlesztésbeli (Mező, 2018), tanulás módszertani (Mező, 2011) és személyiségfejlesztésbeli (Mező, 2016) alprogramok keretében, továbbá e tapasztalatok felhasználása a mesterséges intelligencia kutatásban (Mezó, 2019). A projekt egyik eleme az iskolai jellegú tanulásra vonatkozó OxIPO-modell (2018 előtti szakirodalmakban: IPOO-modell), ami szerint a tanulás egy információ bemenetből (input), feldolgozásból (process) és felhasználásból (output) álló folyamat. E folyamatot pedig olyan háttérváltozók befolyásolják még, mint a tanuló képessége, motivációja, ismeretei, módszertani tudása.
$\mathrm{Az}$ input és az output információk mennyiségi és minőségi szempontból háromféle relációban állhatnak egymással, s így háromféle tanulási stratégia írható le:

1) információveszteséggel járó tanulás esetén: input $>$ output,

2) reproduktív tanulás esetén: input $=$ output,

3) produktív, információtermelő tanulás esetén: input < output.

A tanulás során végbemenő információfeldolgozás eredményessége nagy mértékben függ a tanulásszervezéstől (organizációtól).

Tanulás/tanítás szervezési szempontból az (önállóan vagy a tanárok által szervezett) ismeretszerzés egy lehetséges módja - a hagyományos iskolai ismeretközvetítéssel jellemezhető tanulási-tanítási gyakorlat mellett - a felfedez(tet)éses tanulás lehet. Ennek modernkori úttörői Jerome Bruner és Joseph Schwab.

Jerome Bruner (1961) felfedezés általi tanulás (learning by discovery, magyar nyelven „felfedezéses tanulás”-ként ismertté vált) koncepcióját hamarosan követte Joseph Scwab (1962) felfedeztetéses tanulással (inquiry-based learning - megj.: Schwab eredetileg az enquiry szót használta) kacsolatos felvetése. Mindkét megközelítés közös lényege: az ismereteket ne készen kapja a tanuló, hanem fedezze fel azokat, miközben az ismeretszerzés mellett a tudományos gondolkodást is gyakorolja. A tanulóknak így lehetőségük van problémákat felvetni, vagy mások által felvetett problémákat feltárni, aktívan részt vesznek az információgyüjtésben, 
kérdések és hipotézisek létrehozásában és tesztelésében, az eredmények értelmezésében, s mindezek alapján akár tudományos, műszaki vagy múvészi produktumokat hozhatnak létre (v.ö.: Anderson, 2006) - ezzel lényegében az OxIPO-modell szerinti produktív tanulást valósítanak meg.

Schwab (1962) már felvetette, hogy attól függően, hogy a tanár mennyire irányítja, a tanulás lehet nyitott (nem vagy kevésbé irányított) vagy zárt (irányított), továbbá lehet megerősítő vagy felfedező jellegű, a tanulótól várt aktivitástól függően. Később Herron (1971) attól függően, hogy a felfedeztetni kívánt probléma, annak megoldási módszere, illetve a végeredmény adott-e, a tanulás négy szintjét különböztette meg a felfedeztetés szempontjából:

0. szint: a tanuló számára adottak a problémák, a prooblémamegoldás- hoz szükséges teendők és a várható eredmények.

1. szint: a tanuló számára megadott a probléma és megoldási módszere, azonban a végeredményt a tanulónak kell felismernie, megértenie, megfogalmaznia.

2. szint: a tanuló számára megadják a problémát, de a problémamegoldás módszerei és a válaszok a tanulóktól függnek.

3. szint: a tanuló számára nincs megadva sem a probléma, sem annak megoldási módszere vagy a megoldás végeredménye.

Herron felosztását többen tovább finomították (lásd: Bell, Smetana és Binns, 2005) - az 1. táblázatban például Banchi és Bell (2008) alapján közölt átdolgozás látható.

\section{1. táblázat: A felfedeztetô" tanulás szintjei Banchi és Bell (2008) alapján a Szerző által átdolgozva}

\begin{tabular}{|c|c|c|c|}
\hline A FELFEDEZÉS SZINTJE & $\begin{array}{l}\text { PROBLÉMA } \\
\text { (KÉRDÉS)* }\end{array}$ & $\begin{array}{l}\text { MÓDSZER } \\
\text { (ELJÁRÁS)* }\end{array}$ & $\begin{array}{c}\text { EREDMÉNY } \\
\text { (MEGOLDÁS)* }\end{array}$ \\
\hline $\begin{array}{l}\text { 1) Megerősítő felfedezés (Confirmation Inquiry) } \\
\text { A tanulók egy cselekvésen keresztül megerôsítik egy } \\
\text { témával kapcsolatos ismereteiket. }\end{array}$ & $\begin{array}{l}\text { A TANÁR } \\
\text { által megadott }\end{array}$ & $\begin{array}{l}\text { A TANÁR } \\
\text { által megadott }\end{array}$ & $\begin{array}{l}\text { A TANÁR } \\
\text { által megadott }\end{array}$ \\
\hline $\begin{array}{l}\text { 2) Strukturált felfedezés (Structured Inquiry) } \\
\text { A tanulók a tanár által adott problémát, a tanár által } \\
\text { adott módszerrel vizsgálják, de az eredményt } \\
\text { önállóan fogalmazzák meg. }\end{array}$ & $\begin{array}{l}\text { A TANÁR } \\
\text { által megadott }\end{array}$ & $\begin{array}{l}\text { A TANÁR } \\
\text { által megadott }\end{array}$ & $\begin{array}{c}\text { A TANULÓ } \\
\text { teljesítménye }\end{array}$ \\
\hline $\begin{array}{l}\text { 3) Irányított felfedezés (Guided Inquiry) } \\
\text { A tanulók a tanár által felvetett problémát vizsgálják } \\
\text { a saját maguk által választott módszerrel, és saját } \\
\text { maguk fogalmazzák meg a vizsgálatuk eredményét. }\end{array}$ & $\begin{array}{l}\text { A TANÁR } \\
\text { által megadott }\end{array}$ & $\begin{array}{c}\text { A TANULÓ } \\
\text { választja meg }\end{array}$ & $\begin{array}{c}\text { A TANULÓ } \\
\text { teljesitménye }\end{array}$ \\
\hline $\begin{array}{l}\text { 4) Nyitott felfedezés (Open Inquiry) } \\
\text { A tanulók önállóan választják meg a vizsgálandó } \\
\text { prob-lémát, a megoldási módszert és önállóan } \\
\text { fogalmazzák meg az eredményt is. }\end{array}$ & $\begin{array}{c}\text { A TANULÓ } \\
\text { választja meg }\end{array}$ & $\begin{array}{l}\text { A TANULÓ } \\
\text { választja meg }\end{array}$ & $\begin{array}{c}\text { A TANULÓ } \\
\text { teljesitménye }\end{array}$ \\
\hline
\end{tabular}


A felfedeztető tanulással rokonságot mutat a dizájnalapú tanulás (design based learning), a kutatásalapú tanulás (research based learning), illetve a probléma alapú tanulás (problem based learning) - v.ö.: Kalocsai és Varga (2015), Varga (2015).

Megjegyzendő továbbá, hogy projektmódszerrel kombinálva is megvalósulhat felfedeztető tanulás, illetve élménypedagógiai kontextusban is (Mező, 2015a).

\section{Felfedeztetéses tanulás}

\section{az OxIPO-modell aspektusából}

$\mathrm{Az}$ OxIPO-modell eredetileg az iskolai jellegû tanulás módszertani problémáira fókuszált. A tanulás Input fázisában például a témaválasztás, az információ források kutatásának, illetve azok felhasználásának problémakörét tárgyalta. A Process fázisban az értő tanulás és a memorizálás problémáit azonosította. Végül az Output fázisban a tanultak szóbeli, írásbeli és egyéb viselkedéses jellegű visszaadásának problémái aznosíthatók és fejleszthetők a modellre épülő módszertan révén (lásd: Mező, 2011). A tanulásszervezés esetében pedig a tanulásnak kedvező környezet megteremtésének, az időgazdálkodásnak, a hatékony tanulási algoritmusnak és a tanulás finanszírozásának témakörei kerültek a figyelem fókuszába.

E modell ugyanakkor kiterjeszthető az információfeldolgozás bármely típusára, így a tudományos kutatásra (Mező és Mező, 2019), azon keresztül pedig a felfedeztető tanulásra is.
Az OxIPO-modell alapján a felfedeztető tanulás tervezése, szervezése során az alábbiakat szükséges végiggondolni:

\section{Az Input fázisban}

1.1. A kutatasi téma, probléma megválasztása, beleértve a kutatási kérdések és hipotézisek megfogalmazását is.

1.2. Az adatforrások (szakirodalom, illetve vizsgálati minta kiválasztása, felkutatása, vizsgálati módszerek és eszközök megválasztásastb.).

1.3. Az adatforrások használata (értő, gyors és kritikus olvasástól, a vizsgálati minta előkészítéséig, személyek esetében a kapcsolatfelvételig, a vizsgálati módszerek és eszközök használatáig és az adatgyüjtésig terjedő teendők).

\section{A Process fázisban:}

2.1. Adatfeldolgozás, -elemzés (adatbázisba szervezés, kvalitatív/kvantitatív elemzés, matematikai statisztikai elemzés, stb.).

2.2. Következtetések levonása (eredmények összevetése szakirodalmi adatokkal, lehetséges okok, következmények, gyakorlati hasznosíthatóság, korlátok, további kutatási lehetőségek felvetése).

3. Az Output fázisban:

3.1. Szóbeli prezentáció (például: előadás konferencián)

3.2. Írásbeli prezentáció (például: referátum, tanulmány, könyv írása)

3.3. Egyéb output: például termék, szolgáltatás jellegű innováció.

4. Az Organizáció során:

4.1. Kutatás környezeti feltételeinek megteremtése (például: eszközök beszer- 
zése, helyszín biztosítása, személyi feltételek biztosítása).

4.2. Időgazdálkodás (például: a kutatás ütemezése).

4.3. Eljárás szervezése (például: a kutatás foylamatának megtervezése, megvalósítása).

4.4. Finanszírozás (a kutatással járó kiadások, bevételek tervezése, szervezése).

A felfedeztető tanulás legszélsőségesebb formájában, az 1. táblázatban közölt nyitott felfedezés (Open Inquiry) esetében minden fent jelzett pontott az önálló kutatási/tanulmányi tevékenységet végző kutató/tanuló lát el (lásd például a $\mathrm{K}+\mathrm{F}$ Stúdió Kft., a Kocka Kör Tehetséggondozó Kulturális Egyesület és a Debreceni Egyetem egyetemistáknak szóló interdiszciplináris kutatási projektjeit - v.ö.: Mező és tsai, 2018, Mező, Mező és Mándy, 2019). Minél több pontban kap segítséget tanárától, mentorától, témavezetőjétôl, annál kevésbé lesz rá jellemző az önálló, nyitott felfedezés.

A fentieket átgondolva belátható, hogy a nyitott felfedezés olyan módszertani felkészültséget igényel, ami sokszor még az egyetemi képzésnek sem sajátja, s leginkább a PhD-képzésben jelenik meg. Ugyanakkor megfelelő kutatásmódszertani felkészítéssel akár középiskolások, vagy kiemelkedően tehetséges általános iskolások is alkalmassá tehetők a nyitott felfedezések megtételére (lásd például a Kutató Diákokért Egyesület eredményeit: www.kutdiak.hu).
A tanulók szélesebb köre számára lehet elérhető az irányított felfedezés (Guided Inquiry - v.ö.: 1. táblázat), és még szélesebb körben (és még kevesebb kutatásmódszertani előkészítéssel) valósulhat meg a strukturált felfedezés (Structured Inquiry), valamint a megerősítő felfedezés (Confirmation Inquiry).

\section{A „Tudomány újratöltve”}

$\mathrm{Az}$ alábbiakban az irányított, a strukturált és a megerősítő felfedezésre (v.ö.: 1 . táblázat) lehetőséget adó és a tanulás OxIPO-modelljén alapuló módszertant mutatunk be, ami a „Tudomány újratöltve" című (Mező, 2021) kiadványban került kidolgozásra - támogató: Nemzeti Kulturális Alap (azonosító: 201102/3476).

\section{n<a \\ Nemzeti Kulturális Alap}

A „Tudomány újratöltve” projekt a következő önismereti jellegű kérdéssel fordul a résztvevői felé:

Vajon képesek lennénk ugyanarra a szellemi teljesítményre, mint Kopernikusz, Galilei, Mengyelejev, Mendel, Darwin, Galton, Semmelweis stb., ha rendelkezésünkre állnának ugyanazok az információk, mint amelyekből ők alkották meg világhírű, korszakos felfedezéseiket? 
A kérdés eldöntésére szellemi párbajok révén tehetik magukat próbára az érdeklődők. E szellemi párbajok közös jellemzői:

A szellemi párbajok tudománytörténeti alapon nyugszanak és korábbi, mások általi felfedezések megismétlésére adnak lehetőséget. Következmény: kollektív (például világelsőségként jellemezhető) szinten originális felfedezések így nem születhetnek ugyan, de egy-egy adott tanúló szempontjából mégis igen eredetinek számító felfedezéseket facilitálhatnak a szellemi párbajok. A tehetségazonosítás, és a -gondozás szempontjából pedig mindenképpen figyelemre méltó az a diák, aki önmagától képes a tudománytörténeti jelentôségű felfedezésekre, még ha az elsőség nem is az övé, és az is lehet, hogy már évezredekkel előtte eljutott valaki az adott felfedezésig. Például: a Pithagorasz-tétel önálló felismerése akkor is hatalmas szellemi teljesítmény egy diáktól, ha e tudás máskülönben már több ezer éves kultúrkincsünk.

Három szereplóje van a szellemi párbajoknak. A szellemi párbajokat a felfedeztetéses tanulást szervező tanár készíti elő. Mindegyik szellemi párbajban van egy kihívó fél: a tanuló, és legalább egy kihívott fél: az(ok) a korabeli felfedező(k), tudós(ok), aki(k) szellemi teljesítményét újra felfedezhetik a kihívók (ha tudják).

A három menetbôl álló szellemi párbajok során a felfedezés három szintjén van le- hetősége kipróbálni magukat a résztvevőknek (v.ö.: 1. táblázat, 1. melléklet):

1. menet: az irányitott felfedezés lehetöségét biz̨tositja. A kihívó fél (vagyis a tanuló) számára prezentált input összegzi azokat az ismereteket, amelyek minimálisan szükségesek lehetnek az adott szellemi párbaj témájába vágó (újra)felfedezés megfogalmazásához (1. ábra). A kihívó fél ekkor még nincs tájékoztatva sem a kihívott fél személyével, sem a felfedezés konkrét témájával, módszerével és eredményével kapcsolatban. Erre azért van szükség, hogy a tanuló ne emlékezetből idézzen fel, reprodukáljon ismereteket egy adott személy (például: Mendel) vagy egy adott téma (például a monogénes öröklődés törvényei) alapján, hanem önálló információfeldolgozó szellemi munka révén juthasson el a megadott inputokból levonható következtetésre, a voltaképpeni felfedezésre (outputra).

Amenyiben a diák ezen a szinten hasonló (netán jobb!) eredményre jut, mint a kihívott fél, akkor joggal lehet büszke magára, hiszen a tudománytörténet óriása(i) által elérthez hasonló teljesítményt mondhat magáénak. Az OxIPO-modell szempontjából ez produktív információfeldolgozásnak felel meg. A tanulót a további tehetségsegítés során kutatás módszertani tréningbe vonhatjuk be, amivel a nyitott, önálló felfedezésre ösztönző tanulást készíthetjük elő.

Ha a tanuló ezen a szinten nem jutott el a felfedezésig, akkor a 2. menetben, a strukturált felfedezés során próbálkozhat tovább. 
1. ábra: az irányitott felfedezés lehetôségét adó példafeladat a „Tudomány üjratöltve” projektböl (Mezó, 2021, 40. о.)

\section{SZELLEMI PÁRBAJ / 1. MENET:}

A KIHÍVÓ (AZ OLVASÓ) ÖNÁLLÓ FELFEDEZÉSE

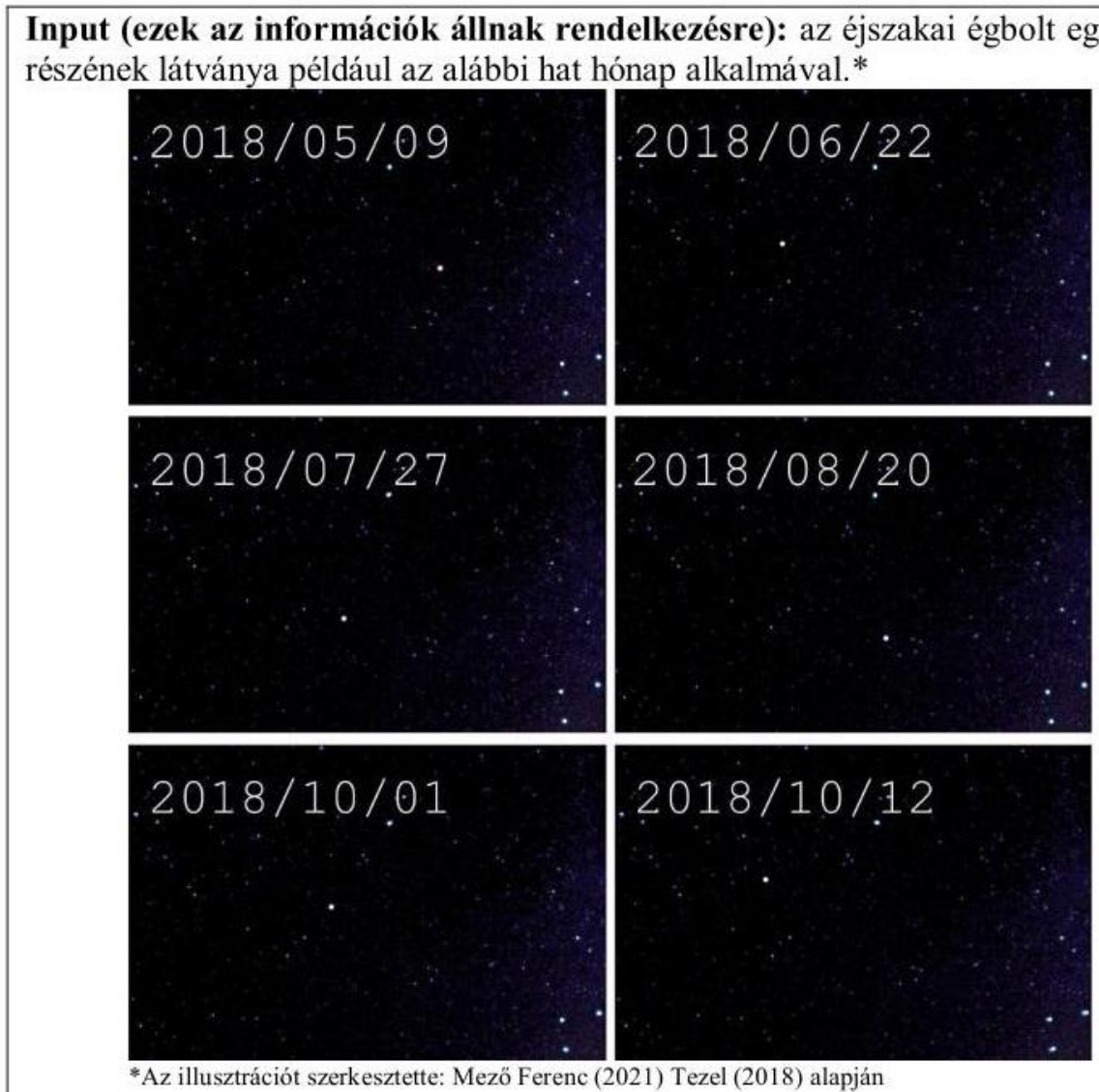

Output (az információfeldolgozás eredménye, a felfedezés):

Innováció (a felfedezés gyakorlati, üzleti hasznosítása):

Mire használható fel a felfedezés? Milyen termék és/vagy szolgáltatásnak lehet az alapja?

Termék:

Szolgáltatás: 
2. menet: a strukturált felfedezés lehetöségét nyújtja. Ebben a feladatban az 1. menetben megadott inputok kiegészülnek a problémamegoldás módszerére vonatkozó újabb információkkal, vagyis azzal, hogy mit kell tenni az 1. menetben közölt inputokkal. De a téma és a kihívott fél személye továbbra sem kerül bemutatásra (lásd: 2. ábra).

Az így létrejövő tanulási szituáció hasonlít ahhoz a helyzethez, mint amikor egy vezetőkutató vagy tanár kiadja az asszisztensének/diákjának a (pl. labordiagnosztikai) feladatot: „Ezekkel az adatokkal, mintával (input), eszközökkel ezt és ezt csináld (ezt tedda process során)!" A végeredményként (outputként) létrejövő felfedezés közlése a kutatóval/tanárral pedig az asszisztens/tanuló feladata. Sikeres (újra)felfedezés esetén produktív tanulásra tanári segítséggel képes személyről van szó. Tehetségsegítés további céljaként az önálló, produktív tanulás alapjainak elsajátítását javasoljuk az OxIPO-minimum tanulásfejlesztő programban (lásd: Mező, 2011, www.kpluszf.com).

3. menet: a megerösitó felfedezés lehetósége. A kihívó felek megismerik a konkrét témát, a kihívott felet, a kihívott fél számára minimálisan rendelkezésre álló inputot, a kihívott fél problémamegoldásának módszerét és gondolatmenetét (=process), és a kapott végeredményt (= output), s reprodukálhatják e folyamatot (lásd: 3. ábra). A 3. menet nyújt lehetőséget az önellenőr- zésre is az 1-2. menetben teljesítők számára.

Az a tanuló, aki a rendelkezésre bocsátott inputok alapján így jut el a végkövetkeztetésig (= output) az reproduktív módon szerezte meg a témával kapcsolatos tudást. Számára a produktív tanulás módszertanát gyakoroltató OxIPO-minimum programot kifejezetten javasolhatjuk (lásd: Mező, 2011, www.kpluszf.com).

Innovatív gondolkodásra nevelés: minden szellemi párbaj minden menete végén megtörténik a tanulók ösztönzése arra, hogy megfogalmazzák, hogy milyen termék vagy szolgáltatás jellegű innováció formájában lehetne hasznosítani a felfedezést (lásd: 1-3. ábrák alsó szekcióját).

A 3. menet vonatkozó részében ezzel kapcsolatos rövid ismeretközlésre is sor kerül.

A téma fejlódéstörténete bemutatásra kerül az egyes szellemi párbajok kapcsán. Így a tanuló képet kaphat arról, hogyan alakult a téma az őskortól a kihívott fél színrelépéséig vagy akár napjainkig. Lehetőség van arra is, hogy a téma jövőbeli alakulásával kapcsoaltos felvetések is megvitatásra kerüljenek. Természetesen e tudománytörténeti összefoglalók akár a tanulók önálló projekt tevékenységeinek eredményeként is létrejöhetnek.

A kibivott fél életrajza, s felfedezésének története is kapcsolódhat az egyes szellemi párbajokhoz. A tanuló így nem csak arról 
2. ábra: a struktúrált felfedezés lehetöségét adó példafeladat a „Tudomány üjratöltve” projektböl (Mezó, 2021, 41. o.)

SZELLEMI PÁRBAJ / 2. MENET:

A KIHÍVÓ (AZ OLVASÓ) RÉSZBEN ÖNÁLLÓ FELFEDEZÉSE

Input (ezek az információk állnak rendelkezésre): az előző párbajok tapasztalata, valamint az 1. menetben közölt input.

Process (az információfeldolgozás során ezt kell tenni): hasonlítsuk össze a csillagos égboltot különböző időpontokban ábrázoló fenti képeket!

Output (az információfeldolgozás eredménye, a felfedezés):*

Az alábbi mondat kipontozott részére az a) és b) betüvel jelzett lehetőségek közül írjuk be azt, amelyik helyesen egészíti ki a mondatot!

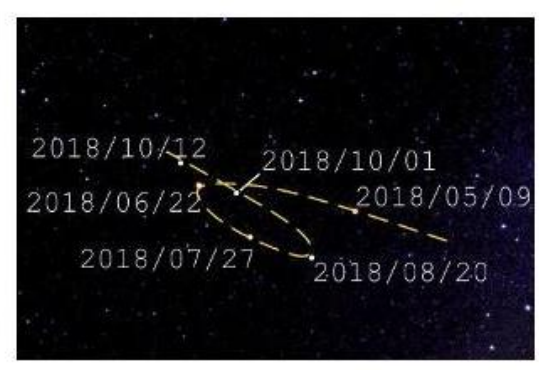

Az illusztrációt szerkesztette: Mező Ferenc (2021) Tezel (2018) alapján

A csillagos égboltot különböző időpontokban ábrázoló fenti képeken a csillagok ... egymáshoz képest látszólag mindig ugyanúgy helyezkednek el, együtt mozognak.

Választási lehetőségek:
a) egy kivételével (!)
b) (kivétel nélkül!)

A kivételnek tekintett égitest látszólag hol előre, hol hátra vándorol a többi csillaghoz képest (amelyek egymással együtt mozognak ugyan, de a ...csillaggal szemben egymáshoz képest állócsillagoknak tekinthetők).

Választási lehetőségek:
a) látható
b) vándor

\section{Innováció (a felfedezés gyakorlati, üzleti hasznosítása):}

Mire használható fel a felfedezés? Milyen termék és/vagy szolgáltatásnak lehet az alapja?

Termék:

\section{Szolgáltatás:}


3. ábra: a struktúrált felfedezés lehetöségét adó példafeladat a „Tudomány újratöltve” projektböl (Mezó, 2021, 42. о.)

\section{SZELLEMI PÁRBAJ / 3. MENET: A KIHÍVOTT FÉL FELFEDEZÉSE}

\section{A kihívott fél: több ezer éve élt ismeretlen személy(ek)}

Input (a kihívott fél így jutott információkhoz): az előző párbajok tapasztalata, valamint több hónapon át megfigyelte a csillagokkal teli égboltot és a csillagok egymáshoz viszonyított helyzetét.

Process (a kihívott fél az információfeldolgozás során ezt tette): összehasonlította csillagok aktuálisan látott helyzetét azok (emlékezetéből felidézett) olykor hónapokkal korábban látott helyzetével.

Output (a kihívott fél felfedezése): a csillagos égboltot különböző időpontokban megtekintve feltünik, hogy a csillagok egy kivételével egymáshoz képest látszólag mindig ugyanúgy helyezkednek el, együtt mozognak. A kivételnek tekintett égitest látszólag hol elöre, hol hátra vándorol a többi csillaghoz képest (amelyek egymással együtt mozognak ugyan, de a vándor csillaggal szemben egymáshoz képest állónak tekinthetők). Megjegyzés: a 3. szellemi párbaj 1. és 2. menetében a képeken a Mars bolygó látható.

\section{Innováció (a felfedezés gyakorlati, üzleti hasznosítása):}

Mire használható fel a felfedezés? Milyen termék és/vagy szolgáltatásnak lehet az alapja?

Termék: a felfedezés szellemi produktumaként létrejöhetett az állócsillag (röviden: csillag) és a ,vándorcsillag” (másképp: ,,bolygócsillag”, röviden: bolygó) fogalma. A bolygók fogalmának kialakulása, illetve a szabad szemmel megfigyelhető öt bolygó (a Merkúr, a Vénusz, a Mars, a Jupiter és a Szaturnusz) azonosítása tette lehetővé a geocentrikus (Földközpontú), később a heliocentrikus (Napközpontú) világképek kialakítását - amelyek ma már egyaránt tévesnek bizonyultak, de tudománytörténeti jelentőségük így is vitathatatlan.

Szolgáltatás: a „bolygók” ismerete alapján lehetővé váltak további csillagászati megfigyelések, valamint a bolygókra is hivatkozó áltudományos babonával és asztrológiával (csillagjóslással), mint szolgáltatással történő (vissza)élés is. 
tájékozódhat, hogy ki volt a felfedező és mit fedezett fel, hanem arról is, hogy a kihívott fél mikor, hány éves korában, mennyi idő alatt és hogyan tette meg felfedezését. Ez segítheti a tanulót abban is, hogy igazán megértse a kihívott fél (talán jövőbeni példaképe) szellemi nagyságát, hiszen beláthatja, hogy esetenként hiába állt rendelkezésre több tízezer év a több milliárd fős emberiség számára, mégis az adott kihívott fél volt az első (ismert) felfedezője egy adott tudományos eredménynek.

A lehetóségehez igazodó költség- és eszközigény jellemzi az egyes szellemi párbajokat. A tanulásszervezés során előfordulhat olyan szituáció, amikor költség- és eszközigényes vizsgálatokra is lehetőség van, más esetekben pedig előfordulhat, hogy az inputokat is legfeljebb például írott, rajzolt, fotózott, legfeljebb táblázatos formában tudjuk a tanulók rendelkezésére bocsátani, és a vizsgálatok is csak a vizsglati tervek szintjén kerülhetnek kidolgozásra, megbeszélésre.

\section{Módszertani nehézségek}

A „Tudományy újratöltve” típusú felfedeztetéses tanulást célzó programok az alábbi módszertani nehézségekbe üt-közhetnek:

\section{A kihivott és a kihivó fél eltéró élethelyzete:}

A kihívott felek (a korabeli tudósok, felfedezők) és a kihívók (a tanulók) közötti különbségek az OxIPO-modell aspektusából például az alábbiak lehetnek:
Különbségek a tanulásszervezés (organizáció) tekintetében:

- A környezet, a helyszín különbségei: a kihívottak és kihívók eltérő korban éltek, eltérő fizikai, technológiai, társadalmi környezetben. A kihívott felek a szellemi teljesítményeiket a mindennapok örömei és kínjai, az egykori betegségek és háborúk körülményei között tették, netán attól rettegtek, hogy az inkvizíció által kiszabott halálos ítélet vár rájuk, ha újonnan szerzett felfedezéseiket közzéteszik vagy nyílvánosan nem vonják viszsza. Másoldalról: a tanulóknak is lehetnek olyan sajátos tulajdonságai és élethelyzetei (és nem csak a kiemelt figyelmet igénylő tanulók esetében), amelyek nem voltak jellemzők a kihívott felekre. Sajnos nem ismerünk lehetôséget arra, hogy e módszertani problémát kiküszöböljük.

- Idóbeli különbségek: az inputok (a következtetések alapjául szolgáló információk) összegyűjtésének és feldolgozásának időbelisége tekintetében is különbözhet a kihívott és a kihívó felek helyzete. Nem mindig áll rendelkezésünkre infomráció arról, hogy egy felfedezéshez szükséges adatok megszerzéséhez (input) és feldolgozásához (process) menniy időre volt szükség, s így azt sem tudjuk biztosítani, hogy éppen ennyi idő álljon a rendelkezésre a tanulók számára is. Esetenként a kihívott felek hónapokon, éveken át tartó adatgyűjtés után kezdtek el ugyancsak hónapokig vagy évekig tartó adatfeldolgozó munkájukba (vagy éppen egy pillanat alatt érte utol őket a belátással járó AHA-élmény). Az sem mindig ismert, 
hogy a felfedezés és hasznosítása között mennyi idő telt el. A tanulók számára mindenesetre nem életszerű túl hosszú időtartamok adása egy-egy szellemi párbaj esetében. Többek között azért sem, mert nehezen biztosítható, hogy közben ne szerezzenek olyan háttér ismeretet az adott felfedezésről, ami a felfedezés helyett a felidézésbeli teljesítényükről fog majd árulkodni.

- Különbségek a tevékenységek szervezésében: amennyiben például feladatlapos formában közöljük a szellemi párbajhoz minimálisan elégséges inputokat (például hat egymés követő hónapban készült fotót a csillagos égről) a kihívókkal (a tanulókkal), akkor az jelentősen eltérhet a kihívott felek valós kutatási tevékenységétől (például a csillagos égbolt hat hónapon át történő megfigyelésétől).

- Különbségek a finanszírozás terén: a kihívott felek esetenként tetemes pénzügyi ráfordításokat tettek a felfedezéseik érdekében (például egy világkörüli hajoút pénzügyi hátterét keleltt fedezniük valamilyen módon). Ehhez képest nagyságrendileg alacsonyabb lehet a kihívó felek kiadásai.

\section{Különbségek az input esetében:}

- A témaválasztást érintő különbségek: a kihívott felek vagy maguk találtak rá kutatási témájukra vagy megbízták őket azzal. A kihívók azonban „készen kapják” a témákat a felfedezéses tanulást facilitáló pedagógustól. Másrészt a kihívott felek rendelkezhettek egy többé-kevésbé kidolgozott tervvel az adatok gyüjtésével kap- csolatban, ám a kihívónak (a tanulónak) nem kell kutatási tervet készítenie, ha az adatokat „készen” kapja. Ugyanakkor a szellemi párbajok során adható olyan feladat is, amelyben kutatási tervet is kell készítenie a tanulóknak.

- Az információforrások kutatása terén lehetséges különbségek: a tudománytörténet óriásainak nem egy mások által „preparált” ingerkörnyezetből kellett kiválogatniuk a felfedezéseikhez szükséges információkat, hanem akár éveken át kitartó munkával jutottak azokhoz. A kihívott és a kihívó felek adott témával kapcsolatos előzetes tudásáról (vagyis az emlékezetből előhívható inputokról) nincsenek pontos ismereteink, márpedig ez erôsen befolyásolhatja a teljesítményüket.

- Az információforrások használatát érintó különbségek: a kihívott és kihívó felek között ebben a pontban talán a legkisebb a különbség, ha ugyanazokat az érzékszerveket feltételezzük, ugyanazokat az eszközöket biztosítjuk (például nem lehet távcsövet vagy mikroszkópot használni, ha a korabeli felfedezőnek az még nem állhatott rendelkezésére), s feltételezzük, hogy el tudták olvasni a felfedezéshez esetlegesen szükséges szövegeket. Lényeges ugyanakkor, hogy ez csak látszólagos hasonlóság, hiszen a problémamegoldásra vonatkozó azonos felkészítést nem tudjuk garantálni. Könnyen belátható, hogy a napjaink tanulóihoz képest más esélyekkel kezdett mondjuk egy matematikai vagy térlátást igénylő természettudományi problémamegoldásához az az ókori filozófus, aki nem kapott erre vo- 
natkozó modern módszertan (lásd például: Nagyová, 2020; Nagyová és Csáky, 2020; Nagyová, Csáky és Žitný, 2021; Tóth és tsai, 2021) alapján megvalósuló felkészítést.

\section{Különbségek a process aspektusából:}

- lehetséges kü̈lönbségek az információk feldolgozása és megértése terén: elvileg a kihívott és a kihívó fél hasonló intellektuális képességeket (például: érzékelést, észlelést, figyelmet, emlékezetet, gondolkodást) alkalmazhat a problémamegoldás során még, ha évezredek is választják el őket egymástól. Az intellektuális színvonalat tekintve aznban a legtöbb esetben nem áll rendelkezésre információ a kihívott felek (az egykori tudósok) esetében, bár a kihívó felek, a tanulók intelligencia-vizsgálata meg is oldható napjainkban.

Másrészt különbség lehet abban is, hogy milyen kognitív műveletekkel jutnak el a felek (akár ugyanazon) megoldásukhoz.

- Memoriqálást érintő különbségek: míg a kihívott felek számára az általuk felfedezett ismeret memorizálása is életmúvük részének tekinthetô, addig a tanulóktól nem minden esetben elvárt a hosszú távú memorizálás (illetve sok egyéb információ memorizálása is elvárt tôlük).

Módszertani problémát jelent a felfedeztetéses tanulás során, ha felidézés történik a valódi felfedezés helyett: ha a tanuló előzetes tudásában már szerepel az adott felfedezés és története, akkor az előzetes tudása akadálya lehet annak, hogy bizonyíthatóan a tanuló önálló felfedezésének tekinthessünk egy teljesítményt.
Megoldási lehetőség: elővizsgálat alapján olyan témát választunk, amiben úgy tűnik nem jártas a tanuló.

Különbségek lehetnek az output tekintetében is: míg a tanulóktól néhány mondatos szóbeli/írásbeli választ, esetleg rajzos információt, előadást várunk (s csak ritkán jellemző a hosszabb tanulmány, könyv vagy tárgyiasult formában történő összegzés), addig a kihívott felek felfedezéseiket jellemzően nagyobb terjedelemű előadásként, szakcikk formájában vagy könyvként adták közre, esetleg termék vagy szolgáltatás jellegű innováció formájában hasznosították.

Az OxIPO-modell háttérváltozóit tekintve is különbségek lehetnek a kihívott és a kihívó felek teljesítményeiben. Eltérōk lehetnek a rendelkezésre álló képességek, motivációs jellemzők, módszertani és elméleti ismeretek.

Összefoglalva: a szellemi párbajokban tapasztalat teljesítmények alapján a kihívott felekkel történő cáfolhatatlan összevetéseket nem lehet tenni. Azonban jelzésértékű lehet, ha egy tanuló jól teljesít a szellemi párbajok által kínált feladatokban.

\section{Zárógondolatok}

A felfedeztetéses tanulást az ismeretközlés mellett az általában véve vett gondolkodásfejlesztés, illetve (pályaorientációs jelleggel) a kutatóvá nevelés céljá-ból alkalmazható pedagógiai eszköz. Jelen ta- 
nulmányban a „Tudomány újratöltve” projekten keresztúl mutattunk rá a felfedeztetéses tanulás egy, az OxIPO-modell elméleti alapjain nyugvó lehetséges módszertani megközelítésére. Bemutatásra került a felfedeztetéses tanulás szervezésekor felmerülő jellegzetes (s gyakran nem vagy csak nehezen kiküszöbölhető) módszertani nehézségek sora is - melyek általában véve jellemzik a felfedeztetéses tanulást. A felfedeztetéses tanulás ugyanakkor minden nehézség ellenére hasznos eleme lehet a tudományos kutatómunka iránt érdeklődéssel forduló kiemelkedően tehetséges tanulók gazdagító programjainak, pályaorientációs foglalkozásainak (Mező, 2015a; Olteanu, 2019a,b).

\section{Irodalom}

Anderson, R.D. (2006): Inquiry as an

Organising Theme for Science

Curricula. In Abell, S.K. \& Lederman, N.G. (eds.): Handbook on Research on Science Education. Mahwah, NJ:

Lawrence Erlbaum Associates. 807830.

Banchi, H. \& Bell, R. (2008) : The Many

Levels of Inquiry. Science and Children, 46(2), 26-29

Bell, R., Smetana, L. \& Binns, I. (2005):

Simplifying inquiry instruction. Science

Teacher (Normal, Ill.) 72(7), 30-34.

Bruner, J. S. (1961): The act of discovery. Harvard Educational Review 31 (1): 2132.
Herron, M.D. (1971): The nature of scientific enquiry. School Review, 79(2), 171- 212.

Kalocsai J. és Varga A. (2015): A fejlesztés keretei. In Varga A. (szerk.): Gyakorlat - reflexió - innováció. Nevelési-oktatási programok részuételi alapú fejlesztése. Oktatáskutató és Fejlesztő Intézet, Budapest. 6-16. Letöltés: 2021.09.01. Web: https://ofi.oh.gov.hu/sites/default/fil es/attachments/1505767_gyakorlat__reflexio_-_innovacio_beliv.pdf

Mező F. (2011): Tanulás: diagnosztika és fejlesztés az. IPOO-modell alapján. $\mathrm{K}+\mathrm{F}$ Stúdió Kft., Debrecen

Mező F. (2016): A viselkedés elemzése és fejlesztése. $\mathrm{K}+\mathrm{F}$ Stúdió Kft., Debrecen.

Mező F. (2018): Fejlesztő pedagógia - Elmélet és gyakorlati példatár a képességfejlesztés köréböl. K+F Stúdió Kft., Debrecen.

Mező F. (2019): Interdiszciplináris kapcsolódási lehetőségek a mesterséges intelligenciára irányuló cél-, eszköz- és hatásorientált kutatáshoz. Mesterséges intelligenciainterdiszciplináris folyóirat, I. évf. 2019/1. szám. 9-29. doi: 10.35406/MI.2019.1.9

Mezô F. (2021): Tudomány újratöltve - Felfedeztetéses tanulás az OxIPO-modell alapján. K+F Stúdió Kft., Debrecen.

Mező F. és Mező K. (2019): Az OxIPOmodell - az interdiszciplináris kutatások egy lehetséges értelmezési kerete. OxIPO - interdiszciplináris tudományos folyóirat, 2019/1, 9-21. doi: 10.35405/OXIPO.2019.1.9 
Mező F., Mező K. és Mándy Zs..Mester D. (2018)(szerk.): A világ interdiszciplináris megközelitésben 3. Debreceni Egyetem, Debrecen

Mező F., Mező K. és Mándy Zs. (szerk.) (2019): A világ interdiszciplináris megközelitésben - 2019. Debreceni Egyetem,

Debrecen.

Mező K. (2015a): Kreativitás és élménypedagógia. Kocka Kör, Debrecen.

Mező K. (2015b): Pályaorientáció, pályatanácsadás tehetségeseknek. Magisðter - Pedagógusok életmód-és iskolamagazinja 13:2, 57-69.

Nagyová Lehocká, Z. (2020): Manipulációs eszközök a matematikaórán. Katedra - Szlovákiai magyar pedagógusok és szülök. lapja. Roč. 28, č. 2 (2020), s. 26-27.

Nagyová Lehocká, Z., Csáky, A. \& Žitný, R. (2021): Best practices for improving spatial imagination in mathematics, AD ALTA. Journal of interdisciplinary research, 2021, ROČ.11/ Č.01

Nagyová Lehocká, Z. és Csáky A. (2020): A térlátás fejlesztését segítő térbeli eszközök. In Katedra - Szlovákiai magyar pedagógusok és sqülōk lapja. Roč. 28, č. 3 (2020), s. 28-29.

Olteanu, L. L. (2019a): A pályaválasztás során fellépő döntéshozási nehézségek OxIPO - inter-diszciplináris tudományos folyóirat. 2019/1, 53-59. doi: 10.35405/OXIPO.2019.1.53
Olteanu, L. L. (2019b): A pszichológiai tanácsadás szakmai alapprotokollja (recenzió) OxIPO - interdiszciplináris tudományos folyóirat. 2019/4, 89-91. doi: 10.35405/OXIPO.2019.4.89

Réti M. (2011): Felfedeztető tanulás. Új utakon a természettudomány-tanítás megújítása felé. Magyar Tudomány, 172. évf. (2011) 9. sz., 1132-1139.

Réti M., Á. Majer A. (2013): A felfedeztetó tanulás támogatásának eszköze a tanártovábbképzés és a tanári mentorálás során: a PISCES modul (Háttértanulmány). Letöltés: 2021.09.01. Web: https://ofi.oh.gov.hu/sites/default/fil es/ofipast/2013/04/PISCES_Reti_M ajer_2013_hatter_GY_RM.pdf Schwab, J. J. (1962): The Teaching of Science as Enquiry. In Schwab, J.J. \& Brandwein, P. (eds.): The Teaching of Science. New York: Simon and Schuster. 1-103.

Tóth A., Nagy Lehocky Zs., Csáky A. és Sedlák M. (2021): Geometriai vizualizáció a gyakorlatban. OxIPO - interdiszciplináris tudományos folyóirat, 2021/1, 83-95. doi: 10.35405/OXIPO.2021.1.83

Varga A. (szerk.)(2015): Gyakorlat - reflexio - innováció. Nevelési-oktatási programok. részuételi alapú fejlesztése. Glosszárium. Letöltés: 2021.09.01. Web: https://ofi.oh.gov.hu/sites/default/fil es/attachments/glosszarium.pdf 